\title{
US foreign policy under fire over strategy on science
}

[WASHINGTON] The US State Department, criticized in recent years for paying insufficient attention to science and technology, has turned to the National Academy of Sciences for advice on how it should best integrate science policy with foreign policy.

In a letter sent to the academy last month, legal counsel to the department, Wendy Sherman, requested that it conduct a study of the department's science programme. The academy's governing board will consider the request later this month.

Sherman's letter conceded that the State Department "may not be doing as much in the science, technology and health areas as we can". One reason, says Melinda Kimble, Acting Assistant Secretary for Oceans and International Environmental and Scientific Affairs, is a belt-tightening throughout the department that occurred in the mid-1990s.

Funding for science, technology and health is only now beginning to make a modest comeback under Secretary of State Madeleine Albright. Historically, scientific agreements with other countries were associated with Cold War strategy, says Kimble, and became lower priority when the Cold War ended.

Only recently, she says, have senior officials at the department, such as Timothy Wirth, until recently the Under Secretary for Global Affairs, and Stuart Eizenstat, Under Secretary for Economic and Business Affairs, begun promoting science as integral to US environmental and trade strategy.

A 1992 report by the Carnegie Commission on Science, Technology and Government called for "deep-seated reforms" in the way US international science policy is conducted. These included the creation of the post of Counselor for Science and Technology at the department, and a boost to funds and staff for science, technology and health.

But James Watkins, president of the Consortium for Oceanographic Research and Education, says the reforms have not happened, and "if anything, the situation has worsened". Watkins and other witnesses at a congressional hearing last week said that US international science policy remains disjointed. They argued that agencies such as the energy and defence departments and the space agency NASA are left to negotiate their own deals, with little coordination from the State Department or anyone else. The hearing was part of the House of Representatives Science Committee's review of national science policy (see Nature 386, 100; 1997).

Watkins, a former energy secretary under George Bush, complained that 'mega-projects', such as the Superconducting Super
Collider and the International Thermonuclear Experimental Reactor, have suffered from the department's lack of involvement. Climate research and oceanographic studies will be similarly impaired, he says, unless there is "radical surgery on today's ineffective system".

His suggestions include placing scientists in US embassies and for congressional science and foreign relations committees to hold meetings with Albright to emphasize the importance of science to foreign relations.

But Thomas Ratchford, a science policy analyst at a research centre at George Mason University in Arlington, Virginia, suggested looking outside the State Department for answers. Efforts at reform "have in general failed," he said. "It is time to quit trying to fix the system directly through State and to enable the technical agencies to partially fix the system."

Ratchford said other countries often fill diplomatic science posts with people borrowed from technical agencies - a practice the United States may want to try, as career foreign service officers tend to be generalists without scientific expertise. The National Science Foundation would be the logical agency to supply or screen these scientific staff, he said. Kimble hopes the academy study will consider how the department can work with other agencies to help achieve its own objectives.

The witnesses disagreed about how effective international scientific agreements have been. About 3,000 US projects funded in 1995 had some international component, according to a study completed last year by the Rand Corporation at the request of the White House science office. But fewer than 10 per cent were coordinated through the State Department, says Caroline Wagner, a senior policy analyst at Rand. The smaller agency-to-agency agreements tended to be the most effective, she said, and have had a "substantial benefit to the United States".

Ratchford, however, criticized the kinds of cooperative agreements often signed during state visits. "In general these agreements have not been very productive scientifically or diplomatically," he said. "There is the diplomatic and public relations benefit of the initial signing ceremony, but the scientific and technological results have often been nil or close to it."

One reason, Ratchford said, is that "it is difficult for diplomats and White House staffers with little experience in research to construct the framework for a viable research effort in the short time available for planning a presidential trip". Tony Reichhardt

\section{Scientists defy their ethics codes and take gifts from industry}

[WASHINGTON] Life scientists are eagerly accepting gifts from industry even when there are strings attached, according to a US journal. The materials, equipment and trips received often defy universities' ethics rules, says a study in this week's Journal of the American Medical Association (JAMA).

Almost half (43 per cent) of more than 2,000 researchers at 50 top US research universities surveyed for the study (see JAMA $279,995 ; 1998)$ had accepted a gift in the past three years. The most common gifts were biomaterials ( 24 per cent), money ( 15 per cent), research equipment and trips to meetings (11 per cent each).

In many cases, however, researchers who accepted the gifts felt that fairly onerous conditions were attached to them. One-third of gift donors required pre-publication review of any resultant research, and one in five demanded ownership of all patentable results. These demands were most frequently made by donors of biomaterials, such as assays and cell lines.

Eric Campbell, a sociologist at the Health Policy Research and Development Unit at the Massachusetts General Hospital at Boston who conducted the study with a grant from the National Institutes of Health, believes both sets of conditions are cause for concern.

Campbell says previous research of his suggests that industry can ask for publication delays of as long as six months to allow for review. He also points out that most universities have explicit policies on intellectual property rights that do not allow investigators to surrender patent rights.

"Gifts from industry to life scientists are a common and important form of academic-industrial research relationship," his study concludes. "At times it may be prudent for faculty members to 'look at a gift horse in the mouth."

Campbell didn't try to put a cash value on the gifts, saying that the value of such items as biomaterials can be difficult to assess. But two-thirds of recipients regarded the gifts as important to their work.

The study found that male researchers were more likely to get gifts than females, and senior faculty more likely to get them than junior faculty. Recipients were found to be significantly more productive than nonrecipients - even when these gender and status differences were factored out.

In an accompanying editorial in JAMA, Lisa Bero of the Institute for Health Policy Studies at the University of California at San Francisco argues that the study makes "a compelling argument" for fresh guidelines on the acceptance of gifts.

Colin Macilwain 